\title{
EPISTEMOLOGI THOMAS S. KUHN DAN MUNCULNYA \\ ILMU PENGETAHUAN SOSIAL
}

\author{
Sudrajat, Hamka Mujahid Ma'ruf, Ajat Sudrajat, Septi Nur Damayanti \\ Pendidikan IPS, Program Pascasarjana, \\ Universitas Negeri Yogyakarta \\ email:sudrajat@uny.ac.id
}

\begin{abstract}
Abstrak
Pada fase normal science, paradigma yang mapan sudah tidak dilihat secara kritis. Paradigma tersebut sudah dianggap benar begitu saja, taken for granted. Sampai akhirnya, paradigma yang mapan ini digugat karena ada anomali dimana muncul masalah atau pertanyaan-pertanyaan yang tidak sanggup lagi dijawab oleh paradigma lama. Kemudian masuklah pada fase krisis. Pada fase krisis, paradigma lama bertarung dengan paradigma baru. Jika paradigma baru menang dan masyarakat ilmiah menyepakati kebenaran paradigma baru tersebut maka lahirlah apa yang disebut sebagai revolusi saintifik dimana paradigma lama tergeser oleh paradigma baru. Thomas Kuhn tidak melihat klaim objektivitas pengetahuan dari sisi perkembangan pengetahuan itu sendiri. Kuhn melihat objektivitas pengetahuandan keilmuan itu sendiri di dalam perkembangan pengetahuan di dalam pertemuan antarmanusia di dalam masyarakat. Sumber pertumbuhan dan pemekaran bukan saja dari masalah-masalah internal pengetahuan, tetapi dari faktorfaktor sosial yangmajemuk dan dinamis. Akibatnya, tidak ada klaim objektivitas yang bersifat tunggal (kumulatif) di dalam pengetahuan atau keilmuan. Oleh karena itu, semestinya tidak ada ilmu normal yang bertahan terus apalagi menjadi abadi karena pengetahuan atau ilmu selalu berada pada tuntutan dinamika sosial kemanusiaan yang dinamis dan majemuk. Fase normal science cepat ataulambat, akan mengalami anomali, krisis, dan akhirnya terjadilah revolusi dimana paradigma lama digantikan oleh paradigma baru.
\end{abstract}

Kata kunci: Paradigma ilmu sosial, Ilmu pengetahuan sosial, Thomas Kuhn 


\begin{abstract}
On a normal phase of science, the established paradigms have not seen critically. The paradigm is already thought to be granted, taken for granted. Finnaly, the established paradigmbecause there are anomalies where emerging issues or questions that are not answered by withstand the old paradigm. Then go on a phase of the crisis. In the old paradigm, the crisis phase of the fight with a new paradigm. If the new paradigm prevail and the scientific community agreed on the new paradigm of truth then there was born the socalled scientific revolution as the old tergeser the paradigms by which the new paradigm. Thomas Kuhn doesn't see claims objectivity of knowledge of the development of the knowledge itself. Kuhn viewed objectivity of knowledge and science itself in the development of knowledge in the meeting think in the within the community. Source of growth and expansion not only from internal problems, but knowledge of factors.
\end{abstract}

Keyword: paradigm, normal science phase, the phase of crisis

\title{
Pendahuluan
}

Awalnya Thomas Kuhn adalah seorang fisikawan namun berbelok dan menjadi sejarawan ilmu pengetahuan. Karya atau hasil pemikirannya yang menjadi pembicaraan banyak orang adalah teorinya tentang revolusi saintifik. Kuhn berpendapat bahwa perkembangan ilmu pengetahuan tidak terjadi secara akumulatif dan evolutif; ilmuwan sedikit demi sedikit mengembangkan ilmu pengetahuan hasil penemuan ilmuwan yang lebih dulu lahir lalu diteruskan oleh ilmuwan generasi berikutnya dan begitu seterusnya. Menurut Kuhn perkembangan ilmu pengetahuan justru terjadi secara revolusioner. Kalau menurut Ben Agger, Thomas Kuhn, secara radikal merumuskan ulangsejarah sains bukan sebagai suatu perkembangan yang linier tapi sebagai rangakaian pergeseran paradigma yang terputus-putus (Agger, 2006: 50).

Thomas Kuhn menolak pandangan bahwa ilmu pengetahuan merupakan sesuatu yang bebas nilai, tidak terikat, dan empiris. 
Kuhn memahami bahwa ilmu pengetahuan tidak bisa terlepas dari paradigma. Menurut Ulya (2015: 251) suatu paradigma diisi oleh pandangan yang dapat dipengaruhi oleh latar belakang ideologi, relasi kuasa (otoritas), dan fanatisme mendasar apa yang menjadi inti persoalan suatu ilmu.

Apa yang disampaikan di atas benar adanya karena ilmu pengetahuan tidak lahir di ruang kosong. Ilmu pengetahuan lahir dari pikiran-pikiran manusia yang mana manusia ini tidak mungkin bisa dilepaskan dari konteks sosial dan atau konteks latar belakang yang menjadi tempat, waktu, dan kondisi dimana ia dilahirkan dan berkembang. Pengalaman setiap orang sangat unik, bahkan seorang anak kembar sekalipun pasti mempunyai keunikan dibanding saudara kembarnya. Kuntowijoyo mengatakan, seorang yang religius tidak bisa lepas dari teologi agamanya, seorang yang sekuler tidak bisa lepas dari ide sekularisme, dan seorang yang kafir tidak bisa lepas dari ateisme (Agung S., 2013: 215).

Dalam melihat agama, antara Karl Marx dan Hasyim Asy"ari tentu berbeda. Karl Marx melihat agama sebagai sesuatu yang buruk karena agama dan agamawan pada zaman itu di sana, realitasnya memang membelenggu manusia dari kebebasan; agama dijadikan alat untuk meninabobokan masyarakat yang tertindas agar mereka tetap dalam keadaan tidak sadar sehingga tidak melakukan perlawanan. Beda halnya jika agama dipandang oleh Hasyim Asy“ari, agama justru menjadi salah satu penopang semangat yang berpengaruh sangat kuat untuk melawan penindasan (kolonialisme).

Ilmu dan pengetahuan tidak bisa lepas dari latar belakang sosialnya. Bisa jadi suatu teori dianggap benar bukan karena ilmu itu memang benar pada dirinya sendiri melainkan karena kadung 
Septi Nur D, Hamka M, Ajat Sudrajat, Sudrajat

dianggap benar oleh orang kebanyakan atau karena berasal dari orang yang berkuasa dan atau orang sudah yang diakuiotoritasnya. Contohnya, bagi orang-orang berideologi nasionalis, Pancasila sebagai dasar negara Indonesia sudah final. Pancasila sudah dianggap benar dari sananya atau kebenarannya sudah diakui begitu saja (taken for granted), kebenarannya tidak dipertanyakan lagi. Sementara itu, hal yang sama juga terjadi kepada orang-orang Islamis yang meyakini bahwa Islam adalah agama yang mengurusi segala hal termasuk urusan politik sehingga sistem politik terbaik bagi dia adalah sistem politik yang dianggapnya sesuai dengan Islam yang dia pahami. Padahal dalam ranah akademik dan demi kemajuan dunia intelektual, tidak ada satu hal pun yang tidak bisa dan tidak boleh dikritisi.

Dalam buku yang berjudul Masyarakat Terbuka dan Musuhmusuhnya, Karl Popper mengkritik bahwa ada banyak hegemoni tokoh-tokoh besar dalam dunia ilmu pengetahuan. Orang-orang terlalu mengagung-agungkan pemikiran tokoh besar masa lampau. Popper bahkan menggunakan kata pemujaan untuk menggambarkan fakta ini. Ini adalah hal yang tidak benar karena akhirnya ilmu pengetahuan diyakini kebenarannya bukan karena pembuktian bahwa ilmu pengetahuan itu memang benar melainkan dia dianggap benar hanya karena berasal dari tokohbesar yang banyak dipuja. Kenapa Popper berpikir seperti ini? Jawaban Popper simpel, karena mereka bisa saja berbuat salah (Popper, 2008: vii).

\section{Metode Penulisan}

Metode yang digunakan dalam penulisan kajian adalah studi pustaka. Tulisan ini mengkaji mengenai epistemologi saintifik Thomas S Kuhn. Menurut Arikunto, metode ini berisi teori-teori yang mendukung pembahasan topik penulisan (2013:73). Studi 
pustaka menurut Sugiono dalam Halimah (2018:51) adalah kajian teori, referensi, serta literatur ilmiah lainnya yang berkaiatan dengan budaya, nilai dan norma yang berkembang pada situasi sosial yang diteliti. Epistemologi saintifik tidak hanya dapat digunakan dalam menemukan kebenaran ilmu alam, namun juga dalam ilmu sosial.

\section{Pembahasan}

\section{Thomas Kuhn}

Kuhn dengan karyanya "The Stucture of Scientific Revolution" menunjukkan adanya krisis objektivitas akibat revolusi atau pergeseran paradigma di dalam perkembangan sains modern. Kuhn (Watloly, 2013: 343) mengatakan bahwa situasi tersebut sebagai "krisis paradigma yang dikuasai oleh paradigma tunggal ilmu normal yang mapan." Menurut Kuhn, perkembangan ilmu berlangsung secara nonlinear dan nonakumulatif. Tampaknya, setelah mencapai puncak vitalitasnya yang disebut sebagai hakikat pengetahuan tertinggi yang disebut ilmu positivis itu, ternyata ilmu-ilmu positif yang disebut keilmuan modern itu seolah kehilangan tenaga budayanya dan kemudian runtuh karena hilang daya kreatif dan keseimbangannya (Nurnaningsih, 2014: 73). Akibatnya, sains atau keilmuan modern telah berkembang melalui revolusi-revolusi yang membongkar paradigma-paradigma lama dan menggantinya dengan paradigma baru.

Apa itu paradigma? Menurut kamus Merriam Webster, paradigma adalah "a model or pattern for something that may be copied" atau "a theory or a group of ideas about how something should be done, made, or thought about". Sementara itu, 
Septi Nur D, Hamka M, Ajat Sudrajat, Sudrajat

Kuntowijoyo dalam bukunya yang berjudul Paradigma Islam, Interpretasi untuk Aksi mengatakan bahwa paradigma seperti yang dipahami oleh Thomas Kuhn, pada dasarnya realitas sosial itu direkonstruksi oleh mode of thought atau mode of inquiry tertentu, yang pada gilirannya akan menghasilkan mode of knowing tertentu pula (Sidik, 2005: 245). Immanuel Kant, misalnya, menganggap "cara mengetahui” itu sebagai apa yang disebut skema konseptual; Marx menamakannya sebagai ideologi; dan Wittgenstetin melihatnya sebagai cagar bahasa. Berdasarkan penjelasan di atas, bisa dikatakan bahwa Seperti yang sudah dijelaskan di atas bahwa paradigma juga bisa diartikan sebagai suatu cara kita dalam memandang dunia. Kuntowijoyo mencontohkan Al-Quran. Dalam pengertian di atas, paradigma $\mathrm{Al}-$ Quran berarti suatu konstruksi pengetahuan yang memungkinkan kita memahami realitas sebagaimana Al-Quran memahaminya. Konstruksi pengetahuan itu dibangun oleh Al-Quran pertama-tama dengan tujuan agar kita memiliki "hikmah" yang atas dasar itu dapat dibentuk perilaku yang sejalan dengan nilai-nilai normatif Al-Quran, baik pada level moral maupun pada sosial (Kuntowijoyo, 1991: 327).

Perubahan paradigma dalam keilmuan modern seperti sesuatu yang tidak bisa dibayangkan sebelumnya. Hal itu hampir menyerupai apa yang disebut pertobatan dalam dunia keagamaan. Dengan demikian, teori-teori keilmuan yang satu tidak dapat dibandingkan dengan teori-teori dalam paradigma keilmuan lain sebelumnya. Kuhn menamai fakta ini sebagai incommensurability. Setiap paradigma yang berlaku pada masanya masing-masing cocok dan memberikan manfaat bagi masyarakatnya.

Pada abad pertengahan, paradigmanya adalah teosentrisme, kemudian teosentrisme digantikan oleh antroposentrisme, dan kini 
kita memasuki era paradigma biosentrisme. Ketiga paradigma yang saya sebutkan di atas kalau menurut Kuhn tidak bisa dibandingkan. Ketiganya sudah memberikan manfaat dan sesuai dengan perkembangan masyarakatnya pada zamannya masingmasing.

Paradigma zaman modern adalah antroposentrisme dan salah satu alat paling penting dalam peradaban modern yang berparadigma antroposentrisme ini adalah metode ilmiah atau positivisme. Revolusi keilmuan modern yang kekuatannya dibangun atas dasar "positivi: 30 ngan ciri empiris-analitisnya, telah menempatkan ilmu sebagai satu-satunya keilmuan atau kebenaran ilmiah yang sahih tentang kenyataan. Melalui deduksi rasionalisme dan empirisme dengan penerapan hukum alam yang pasti, akhirnya ilmu-ilmu positif mengembangkan konsep teori guna sebuah klaim objektivitas yang murni.

\section{Revolusi Saintifik Thomas S. Kuhn}

Di atas kita sudah melihat beberapa poin dari pemikiran Kuhn. Seperti yang sudah dibahas di pendahuluan bahwa pemikiran Kuhn yang paling terkenal adalah teori Revolusi Saintifik. Rangkaian dari siklus revolusi saintifik terbagi menjadi empat fase yakni, fase sebelum paradigma (pre paradigmatic), fase sains normal (normal science), fase krisis, dan fase revolusi saintifik. Agar lebih jelas, mari kita cermati poin-poin dari revolusi saintifikgagasan Kuhn di bawah ini.

\section{Fase Sebelum Paradigma}

Pada masa Sebelum-Paradigma, tidak ada suatu cara pandang tertentu yang dimiliki oleh orang-orang secara seragam. Belum ada paradigma yang diakui dan digunakan secara masif oleh masyarakat ilmuwan. Pada fase sebelum-paradigma, ilmu dilanda konflik antara mahzab atau alirannya. Komunikasi antara mahzab 
Septi Nur D, Hamka M, Ajat Sudrajat, Sudrajat|

secara intern dan dengan ilmu luarnya serta dengan awam dapat mendewasakan ilmu yang bersangkutan. Demikian proses ilmu mencapai tingkatan sebagai normal science.

\section{Fase Ilmu Pengetahuan Normal}

Fase Ilmu Pengetahuan Normal yang selanjutnya akan kami sebut normal science adalah masa ketika suatu paradigma sudah mapan (Abas, 2012: 346). Oleh karena sudah mapan sehingga orang- orang tidak mempertanyakan lagi kebenaran paradigma tersebut. Paradigma tersebut dipercaya begitu saja atau taken for granted tanpa ada gugatan kepadanya. Bahkan menurut Feyerabend, pada tahap ini paradigma -- meskipun paradigma ilmiah positivistik -sudah menjadi seperti agama, sifatnya dogmatis.

\section{Fase Krisis}

Ini adalah masa ketika paradigma lama sudah dianggap tidak sakti lagi. Manusia merasa bahwa paradigma lama ini tidak lagi mampu untuk menyelesaikan persoalan-persoalan yang mereka hadapi (Fuad, dkk. 2015: 254). Seiring berjalannya waktu, muncul anomalianomali lainnya dan kian menumpuk hingga pada akhirnya menimbulkan krisis kepercayaan para ilmuwan terhadap paradigma. Paradigma mulai diperiksa dan dipertanyakan. Para ilmuwan mulai keluar dari jalur normal science.

Pada fase normal science ilmuwan menjabarkan dan mengembangkan paradigma sebagai metode ilmiah. Selama menjalankan aktivitas ini, para ilmuwan menjumpai berbagai fenomena yang tidak dapat dijelaskan dengan paradigma yang digunakan, yang dinamakan anomali atau krisis. Anomali adalah suatu keadaan yang memperlihatkan adanya ketidakcocokan antara kenyataan (fenomena) dengan paradigma yang dipakai. Paradigma lama tumpul, dianggap tidak mampu lagi menghadapi persoalan-persoalan. Kemudian, kebuntuan-kebuntuan inilah 
yang akhirnya melahirkan suatu paradigma baru. Berasmaan dengan kelahiran paradigma baru ini, saat itu jugalah fase krisis sudah terlewati (Daldjoeni 2014: 163).

Fase krisis ini contohnya bisa kita lihat contohnya dalam perlihan dari era modern ke post modern (Zainuddin, 2016: 119). Saat modernisme mencapai puncaknya, para pemikir menyadari bahwa paradigma modern yang antroposentris ternyata telah membawa manusia kepada jurang kehancuran, mereduksi kesejatian manusia sebagai manusia.

\section{Fase Revolusi Saintifik}

Fase ini adalah dimana suatu paradigma baru lahir dan menggantikan paradigma lama. Pada fase ini, para ilmuwan bisa kembali lagi pada cara-cara ilmiah yang lama sembari memperluas dan mengembangkan suatu paradigma tandingan yang dipandang bisa memecahkan masalah dan membimbing aktivitas ilmiah berikutnya. Proses peralihan dari paradigma lama ke paradigma baru inilah yang dinamakan revolusi saintifik. Pada fase ini, paradigma lama diuji kesaktiannya, apakah dia masih efektif untuk menghadapi masalah-masalah yang dihadapi. Jika ternyata paradigma lama ternyata gagal maka dia akan segera digeser oleh paradigma baru.

Tahapan-tahapan di atas, jika dibuatkan skemanya, kira- kira beginilah skamanya. 
Septi Nur D, Hamka M, Ajat Sudrajat, Sudrajat

The revolutionary character of paradlgm shifts, and the cycllcal nature of sclence ( $a$ schematizatlon of Kuhn. 1970).

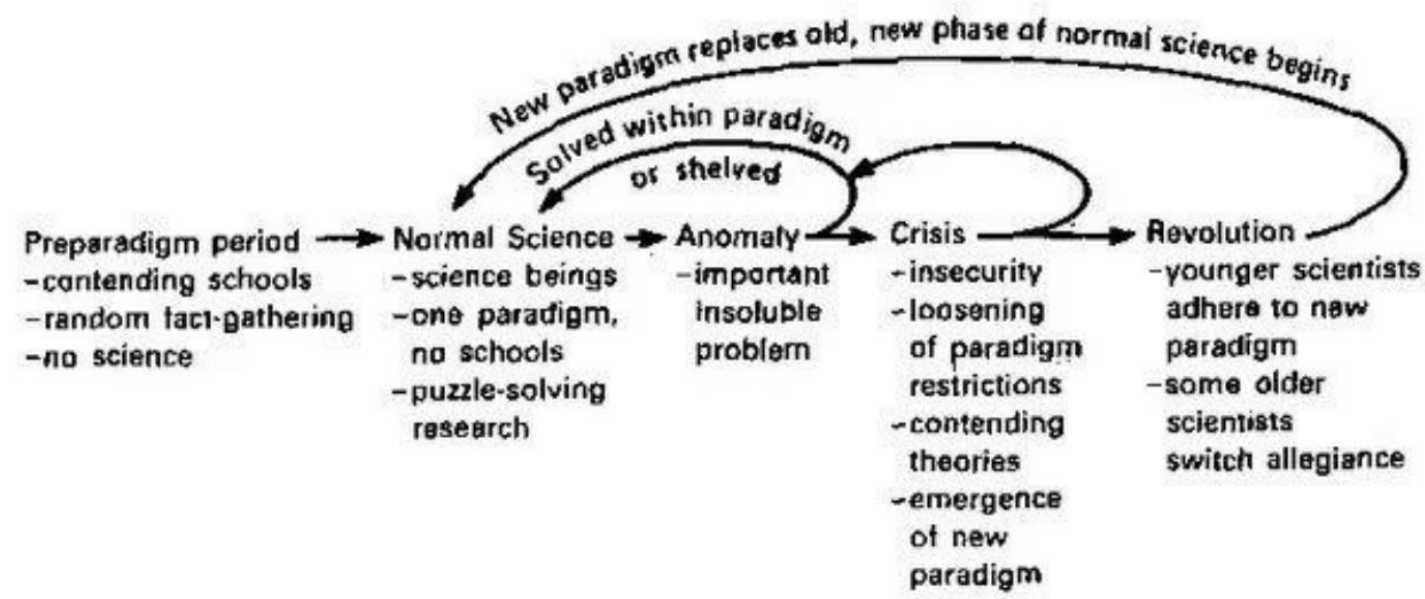

Untuk semakin memantapkan pemahaman kita mengenai teori revolusi saintifik, kami akan mengaplikasikan teori ini ke dalam contoh transisi paradigma modern yang bersifat mekanisreduksionalistis menuju paradigma pasca modern (post modern) yang bersifat sistemis-organis.

Salah satu penopang terpenting dari era modernisme adalah cara berpikir positivistik (Almas, 2017: 90). Dalam perkembangannya, positivisme mengalami banyak sekali pertentangan antara lain dari tokoh-tokoh pemikir eksakta yang merasa bahwa teori-teori positivistik sangatlah menghegemoni pemikiran mereka dan membuat ilmu pengetahuan menjadi berhenti. Menurut Maksum (2014: 274) diantara fisikawan yang melawan dan mengkritik positivisme ini adalah: Thomas Kuhn dengan Revolusi Paradigma-nya, Karl Popper dengan teori Falsifikasi-nya, kemudian juga Feyerabend dengan Antimetode-nya, dan masih banyak lagi tokoh yang mengkritik habis-habisan cara berpikir positivistik.

Sebelum kita masuk pada paragraf-paragraf yang mencoba menelanjangi dan mengkritisi modernisme, mari kita lihat terlebih 
dahulu kronologi singkat tentang dan bagaimana kehebatan dan kontribusi modernisme bagi dunia kita sekarang.

Di abad ke-16 dan ke-17 pandangan dunia abad pertengahan, yang didasarkan pada filsafat Aristoteles dan teologi Kristen, berubah secara radikal. Pengertian alam semesta yang organik, berubah secara radikal. Pengertian alam semesta yang organik, hidup dan spiritual digantikan oleh pengertian dunia sebagai sebuah mesin, dan dunia-mesin menjadi pola yang dominan di dunia modern. Perubahan yang radikal ini dihasilkan oleh penemuan-penemuan baru di dalam fisika, astronomi, dan matematika yang dikenal sebagai Revolusi Ilmiah dan dihubungkan dengan nama-nama seperti Copernicus, Galileo, Descartes, Bacon, dan Newton (Capra, 2002: 32). Menurut Childe, tidak ada periode sejarah sebelum jaman Galileo yakni suatu periode sejarah dimana umat manusia mengalami kemajuan pengetahuan sedemikian pesat atau seringkali berhasil mendapatkan penemuan yang berjangkauan jauh ke depan (Fromm, 2000: 219).

Galileo Galilei melarang ilmu mempelajari kualitas, ilmu dibatasi hanya untuk mempelajari fenomena yang dapat dikur dan dikuantifikasi. Dengan arah yang sama Descartes berpikir bahwa alam semesta material, yang meliputi organisme-organisme hidup adalah sebuah mesin, yang pada prinsipnya dapat dimengerti seluruhnya dengan menganalisa bagian-bagiannya yang terkecil. Kerangka konseptual yang diciptakan oleh Galileo dan Descartes dunia sebagai sebuah mesin yang sempurna yang diatur oleh hukum-hukum matematis yang pasti - disempurnakan dengan gemilang oleh Isaac Newton. Sintesis besarnya, Mekanika Newtonian, merupakan prestasi yang menyempurnakan ilmu pengetahuan abad ke-17 (Capra, 2002: 32-33). Sampai sekarang, 
Septi Nur D, Hamka M, Ajat Sudrajat, Sudrajat

kita bisa merasakan betapa produk-produk teknologi ilmu pengetahuan modern ini sangat besar manfaatnya bagi kehidupan kita sehari-hari; kehidupan kita menjadi lebih mudah, waktu luang kita menjadi lebih banyak, dan lain sebagainya.

Menurut Chris Barker (Maksum, 2014: 309) katamodernisme mengandung makna serbamaju, gemerlap, dan progresif. Modernisme berkaitan dengan bentuk-bentuk kebudayaan yang ditandai dengan rasionalisme, positivisme, empirisme, industri, dan kecanggihan teknologi. Modernisme selalu menjanjikan pada kita untuk membawa perubahan ke dunia yang lebih mapan dimana urusan materi atau kebutuhan jasmani akan terpenuhi, tidak akan ada lagi kelaparan atau kekurangan material, itulah janjinya.

Sekarang janji-janji modernisme belum semua terealisasi. Cita-cita modernisme banyak yang gagal tercapai. Bukan sekadar kegagalan, lebih dari itu, modernisme justru malah membawa kerusakan yang mungkin tidak terbayangkan sebelumnya. Pada akhir abad ke-20, masalah lingkungan menjadi sangat penting. Kita dihadapkan pada serangkaian masalah-masalah global yang membahayakan biosfer dan kehidupan manusia dalam bentukbentuk yang sangat mengejutkan yang dalam waktu dekat akan segera menjadi tak dapat diperbaiki lagi sama sekali (irreversible) (Capra, 2002:11).

Perkembangan modernisme yang pesat menyebabkan adanya dampak negatif yang harus dihadapi manusia. Menurut Anthony Giddens (Maksum, 2014: 311) sisi gelap modernisme menimbulkan berkembang biaknya petaka bagi umat manusia. Pertama, penggunaan kekerasan dalam menyelesaikan sengketa. Kedua, penindasan oleh yang kuat atas yang lemah. Ketiga, ketimpangan sosial yang kian parah. Keempat, kerusakan 
lingkungan hidup yang semakin mengkhawatirkan. Produk akhir yang menimbulkan petaka tersebut, terutama dipicu oleh:pertama, kapitalisme liberal yang menyaratkan kompetisi tiada akhir akan pertarungan pasar. Kedua, industrialisme yangmenyaratkan inovasi tiada henti untuk memenangkan persaingan pasar bebas. Ketiga, lemahnya kekuatan negara di dalam mengemban tugas minimalnya untuk menciptakan tertib sosial yang aman, rukun, damai, dan adil.

Dalam masyarakat yang kapitalistik, manusia hanya menjadi elemen dari pasar. Dalam masyarakat seperti itu, kualitas kerja manusia, dan bahkan kualitas kemanusiaan sendiri, ditentukan oleh pasar. Jika mereka ingin bekerja, maka merekaharus menjual dan menawarkan jasanya ke pasar. Dalam masyarakat kapitalis, dengan demikian, manusia hanya menjadi bulan-bulanan dari kekuatan pasar. Malapetakan kemanusiaan dalam sistem kapitalistik ini ternyata tak lebih ringan dari malapetaka yang dihadapi manusia dalam sistem komunis. Dalam masyarakat komunis, manusia tidak menjadi elemen dari pasar,tapi menjadi elemen birokrasi. Demikianlah, di dalam keduasistem sosial masyarakat modern itu, fungsi manusia turun sekadar menjadi elemen (Kuntowijoyo, 1991: 162).

Rasa kurang berarti, hilangnya kedirian, dan merasa dijadikan sebagai benda. Kecerai-beraian eksistensial tidak nampak jelas karena manusia menjadi identik dengan organisasi sosialnya dan lupa bahwa dia adalah sebuah pribadi; dia menjadi - meminjam istilah Heidegger - “sesuatu” yang bukan pribadi. Dapat dikatakan bahwa dia dalam keadaan "ekstase negatif"; dia melupakan dirinya dengan tidak lagi menjadi “dia”, dengan tidak lagi menjadi pribadi, dan kemudian menjadi benda (Fromm, 2000: 332). 
Septi Nur D, Hamka M, Ajat Sudrajat, Sudrajat|

Krisis sains modern yang menimbulkan petaka kehidupan manusia, menyadarkan ilmuwan untuk merevisi asumsi-asumsi yang mendasari bangunan sains modern. Thomas Kuhn dalam bukunya The Structure of Scientific Revolution mengatakan bahwa pada masa tertentu ilmu normal (normal science) mendominasi aktivitas ilmiah. Tetapi seiring dengan perkembangan dan perubahan, ilmu normal tidak dapat lagi menjelaskan perkembangan yang terjadi. Inilah yang kemudian melahirkan krisis ilmu pengetahuan. Krisis ini menjadi cikal bakal terjadinya revolusi ilmiah. Menurut Kuhn (Maksum, 2014: 313) revolusi ilmiah itu pertama-tama menyentuh wilayah paradigma, yaitu cara pandang terhadap dunia.

Menurut Fritjof Capra, masalah-masalah ini harus dilihat sebagai aspek-aspek yang berbeda dari sebuah krisis tunggal, yakni terutama suatu krisis persepsi. Krisis, itu berasal dari fakta bahwa sebagian besar kita, dan khususnya lembaga-lembaga sosial kita yang besar, mendukung konsep-konsep yang berasal dari pandangan dunia yang kadaluarsa, sebuah persepsi realitas yang sudah tidak memadai lagi. Masih menurut Capra, solusi atas masalah-masalah itu adalah menghendaki suatu perubahanradikal dalam persepsi, pemikiran, dan nilai-nilai kita. Sebenarnya, sekarang ini kita berada pada permulaan sebuah perubahan fundamental pandangan dunia dalam ilmu danmasyarakat, sebuah perubahan paradigma yang sama radikalnya dengan revolusi Copernikan. Konsep-konsep baru dalam fisika telah menimbulkan perubahan mendalam dalam pandangan dunia kita; dari pandangan dunia mekanistik yang berasal dariDescartes dan Newton menjadi suatu pandangan holistik, ekologis (Capra, 2002: 13-14). 
Masalah yang kita hadapi adalah hasil dari perilaku kita sendiri. Perilaku ini erat kaitannya dengan dan didasari oleh paradigma yang kita anut. Masalah dunia yang kita hadapi sekarang; dehumanisasi, kerusakan ekosistem, kemiskinan dan lain sebagainya terjadi karena perilaku manusia. Perilaku manusia yang salah hingga menyebabkan semua masalah ini disebabkan oleh paradigma berpikir yang keliru (Keraf, 2014: 8).

Perubahan dramatis pemikiran yang terjadi dalam fisika pada awal abad ke-20 telah didiskusikan secara luas oleh para fisikawan dan filsuf lebih dari lima puluh tahun. Hal itu menuntun Thomas Kuhn tiba pada „suatu konstelasi hasil-hasil - konsep- konsep, nilai-nilai, teknikteknik, dan sebagainya - yang digunakan bersama oleh komunitas ilmiah dan dipakai oleh komunitas itu untuk mendefinisikan masalahmasalah dan solusi- solusi yang absah". Perubahan-perubahan paradigma, menurut Kuhn, terjadi dalam perubahan-perubahan diskontinyu, dan revolusioner yang disebut "Pergeseran-pergeseran paradigma" (Capra, 2002: 14-15).

Munculnya pasca-modernisme tidak dapat dilepaskan dari faktor eksistensi modernisme itu sendiri karena memang pada dasarnya post modernism lahir sebagai kritik terhadap modernisme atau bisa juga dikatakan bahwa post modernism bertujuan untuk merevisi kekurangan-kekurangan modernisme.

\section{Latar Belakang Kemunculan IPS dipandang dari Perspektif Revolusi Saintifik}

Sejarah perkembangan Pendidikan IPS erat kaitannya dengan perkembangan sejarah di Amerika Serikat. Perkembangan Pendidikan IPS sangat gencar pasca Perang Dunia I, ketika integrasi nasional diperlukan sebagai benteng melemahnya kebudayaan Anglo-Saxon sebagai identitas peradaban mereka. 
Septi Nur D, Hamka M, Ajat Sudrajat, Sudrajat

Istilah IPS di Indonesia baru muncul sekitar tahun 1975-1976. Menurut Noman Somantri dalam Supardi (2011: 183) Pendidikan IPS adalah suatu synthetic discipline yang berusaha untuk mengorganisasikan dan mengembangkan substansi ilmu-ilmu sosial secara ilmiah dan psikologis untuk tujuan pendidikan. Makna synthetic discipline bahwa PIPS bukan sekadar mesintesiskan konsep-konsep yang relevan antara ilmu-ilmu pendidikan dan ilmu-ilmu sosial, tetapi juga melakukan korelasidengan masalahmasalah kemasyarakatan, kebangsaan, dan kenegaraan (Nurdin, 2017: 8).

Materi kajian IPS merupakan perpaduan atau integrasi dari berbagai cabang ilmu sosial dan humaniora sehingga akan lebih bermakna dan kontekstual apabila materi IPS didesain secara terpadu. Konsep yang dibentuk secara multidisiplin seperti multikultural, lingkungan, urbanisasi, perdamaian, dan globalisasi berasal dari konsep disiplin tradisional dan menjadi pemerkayabagi kajian IPS. Jenis materi IPS dapat berupa fakta, konsep, dan generalisasi sehingga dapat berkaitan dengan aspek kognitif, afektif, psikomotorik, dan nilai-nilai spiritual.

Mata pelajaran IPS sangat memerhatikan dimensi keterampilan disamping pemahaman dalam dimensi pengetahuan. Kecakapan mengolah dan menerapkan informasi merupakan keterampilan yang sangat penting untuk mempersiapkan siswa menjadi warga negara yang mampu berpartisipasi secara cerdas dalam masyarakat demokratis. Oleh karena itu, keterampilan meneliti, keterampilan berpikir, keterampilan berpartisipasi sosial, dan keterampilan berkomunikasi sangat diperlukan dalam pendekatan utama pembelajaran IPS.

Kajian epistemologi terhadap gagasan dan pemikiran para pakar Pendidikan IPS di Indonesia, khususnya tentang 
pendefinisian hakikat Pendidikan IPS sebagai bidang kajian, disiplin ilmiah, program sekolah, maupun sebagai profesi merupakan keniscayaan akademik. Dalam epistemologi tentang revolusi keilmuan dan sains, Kuhn menelisik secara lengkap setiap pemikiran dan karya ilmiah individual para pakar dan mengungkapkan kontribusinya terhadap terjadinya revolusi sains. Menurut Saxe dan Nelson dalam Farisi dan Malik (2015: 129) secara epistemologis merupakan persoalan mendasar terkait dengan kejelasan dan kepastian bagi setiap anggota komunitas PIPS mengenai ways of seeing the world and practicing science in it dan adanya perubahan ke arah paradigma baru yang berimplikasi lebih lanjut terhadap perlunya a new and more rigid definition of the field (Kuhn, 1970: 4).

Tindakan sosial merupakan dimensi Pendidikan IPS yang penting karena tindakan dapat memungkinkan siswa menjadi peserta didik aktif. Mereka pun dapat belajar berlatih secara konkret dan praktis. Dengan belajar dari apa yang diketahui dan terpikirkan isu-isu sosial untuk dipecahkan sehingga jelas apa yang akan dilakukan dan bagaimana caranya, para siswa belajar menjadi warga negara yang efektif di masyarakat.

Dimensi tindakan sosial dapat dibelajarkan pada semua jenjang dan semua tingkatan kelas kurikulum IPS. Menurut Sapriya (2012: 56) dimensi tindakan sosial untuk pembelajaran IPS meliputi tiga model aktivitas sebagai berikut:

- Percontohan kegiatan dalam memecahkan masalah di kelas secara bernegosiasi dan bekerjasama. Misalnya, siswa usia 5 tahun bercurah pendapat dengan gurunya tentang tempattempat piknik apa saja sebagai alternatif dan mana yang akan dipilih. 
Septi Nur D, Hamka M, Ajat Sudrajat, Sudrajat|

- Berkomunikasi dengan anggota masyarakat dapat diciptakan, misalnya dengan kelompok masyarakat pecinta lingkungan, masyarakat perajin, masyarakat petani, pedagang dan melakukan survey, pengamatan, serta wawancara dengan pedagang di pasar tradisional.

- Pengambilan keputusan dapat menjadi bagian kegiatan kelas, khususnya pada saat siswa diajak untuk melakukan inkuiri.

\section{Simpulan}

Revolusi saintifik adalah suatu keniscayaan alamiah karena manusia selalu berkembang, manusia selalu berubah. Di masa sekarang manusia mempunyai suatu paradigma yang diyakininya akan membawa kebaikan bagi kehidupannyaDi masa depan bukan tidak mungkin paradigma itu dianggap tidak relevan lagi, paradigma lama dianggap sudah tidak memadai lagi untuk menghadapi berbagai persoalan-persoalan baru hingga akhirnya muncullah paradigma baru. Seperti sebelumnya, kemudian paradigma baru menjadi normal science yang mapan lalu diyakini sebagai paradigma terbaik untuk menghadapi berbagai persoalan di dunia sampai saat terjadi anomal dan krisis lalu terjadi revolusi saintifik lagi. Begitu seterusnya.

\section{Daftar Pustaka}

Agger, B. 2006. Teori Sosial Kritis; Kritik, Penerapan, dan Implikasinya. Yogyakarta: Kreasi Wacana.

Agung S., Leo. 2013. Sejarah Intelektual. Yogyakarta: Penerbit Ombak. 
JIPSINDO No. 1, Volume 6, Maret 2019

Capra, F. 2002. Jaring-Jaring Kehidupan; Visi Baru Epistemologi dan Kehidupan. Yogyakarta: Fajar Pustaka Baru.

1999. Titik Balik Peradaban; Sains, Masyarakat, dan Kebangkitan Kebudayaan. Yogyakarta: Bentang.

Daldjoeni, N. 2014. Pengantar Geografi. Yogyakarta: Penerbit Ombak.

Kuhn, T.S. 1970. The Structure of Scientific Revolutions (Second Edition Enlarged). London: The University of Chicago Press, Ltd.

Fromm, E. 2000. Akar Kekerasan, Analisis Sosio-Psikologis atas Watak Manusia. Yogyakarta: Pustaka Pelajar.

Keraf, A.S. 2014. Filsafat Lingkungan Hidup; Alam sebagai Sebuah Sistem Kehidupan Bersama Fritjof Capra. Yogyakarta: PT Kanisius.

Kuntowijoyo. 1991. Paradigma Islam; Interpretasi untuk Aksi. Bandung: Penerbit Mizan.

Maksum, A. 2014. Pengantar Filsafat: Dari Masa Klasik Hingga Postmodernisme. Yogyakarta: Ar-Ruzz Media.

Popper, Karl R., 2008. Masyarakat Terbuka dan Musuh-Musuhnya. Yogyakarta: Pustaka Pelajar. 
Septi Nur D, Hamka M, Ajat Sudrajat, Sudrajat|

Suharsimi, A. 2013. Prosedur Penelitian Suatu Pendekatan Praktik. Jakarta: Rineka Cipta

Supardi. 2011. Dasar-dasar Ilmu Sosial. Yogyakarta: Penerbit Ombak.

Sapriya. 2012. Pendidikan IPS Konsep dan Pembelajaran. Bandung: PT Remaja Rosdakarya Offset

Watloly, A. 2013. Sosio-Epistemologi Membangun Pengetahuan Berwatak Sosial. Yogyakarta: Penerbit Kanisius.

\section{Jurnal}

Abas, Z. 2012. "Konstruksi Paradigmatis Pemikiran Teologi Islam Kritis”. Jurnal Pemikiran IslamAl-Tahrir, Volume 12, No. 2,hlm. 346

Almas, A. F. 2018. "Sumbangan Paradigma Thomas S. Kuhn dalam Ilmu dan Pendidikan (Penerapan Motode Problem Bassed Learning dan Dicovery Learning)". Jurrnal At- Tarbawi, Volume 3, No. 1, hlm. 90

Farisi, M.I dan Malik, A. 2015. Pendidikan IPS sebagai "Synthetic Discipline": Kajian Epistemologis atas Pemikiran Nu"man Somantri. Jurnal Cakrawala. I. Halm 129 diakses dari https://media.neliti.com/media/publications/85473-IDpendidikan-ips-sebagai-synthetic-discipl.pdf diakses pada Rabu, 24 Oktober 2018 pukul 11: 29 WIB. 
JIPSINDO No. 1, Volume 6, Maret 2019

Fuad. Wibiosono, K. dan Hadi, P. H. 2015. "Kebenaran Ilmiah dalam Pemikiran Thomas S. Khun dan Karl R. Popper: Suatu Kajian Hermeneutika dan Kontribusinya bagi Masa Depan Ilmu". Jurnal Filsafat Universitas Gadjah Mada, Volume 25, No. 2, hlm. 254

Halimah, M. 2018. "Pandangan Aksiologi terhadap Surrogate Mother". Jurnal Filsafat Indonesia. Vol 1. (1). Halm 51

Nurdin, M. F. 2017. “Sosiologi Kontemporer: Filsafat dan Orientasi Perubahan". Sosioglobal; Jurnal Pemikiran dan Penelitian Sosiologi, Volume 2, No. 1, hlm. 8

Nurnaningsih. 2014. Dekonstruksionisme dan Postmodernisme. Jurnal Diskursus Islam, Volume 2, No. 1, hlm. 73

Sidik. 2005. "Paradigma Islam dan Transformasi Sosial (Studi Pemikiran Kuntowijoyo)". Jurnal Hunafa, Volume 2, No. 3, hlm. 245

Ulya, I dan Abid, N. 2015. Pemikiran Thomas Kuhn dan Relevansinya terhadap Keilmuan Islam. Jurnal Ilmu Aqidah dan Studi Keagamaan. Vol3, 2. Halm 251

Zainuddin, A. 2016. "Islam dalam Era Post-Modern; Melacak Periodisasi Pemikiran dalam Studi Keislaman”. Jurnal Studi Islam Miyah, Volume XI, No. 1, hlm. 119 